Article

\title{
Climate Change Adaptation and Sectoral Policy Coherence in the Caribbean
}

\author{
Clint T. Lewis * and Ming-Chien Su
}

check for updates

Citation: Lewis, C.T.; Su, M.-C. Climate Change Adaptation and Sectoral Policy Coherence in the Caribbean. Sustainability 2021, 13, 8518. https://doi.org/10.3390/ su13158518

Academic Editor: Constantinos Cartalis

Received: 29 June 2021

Accepted: 14 July 2021

Published: 30 July 2021

Publisher's Note: MDPI stays neutral with regard to jurisdictional claims in published maps and institutional affiliations.

Copyright: (c) 2021 by the authors. Licensee MDPI, Basel, Switzerland. This article is an open access article distributed under the terms and conditions of the Creative Commons Attribution (CC BY) license (https:/ / creativecommons.org/licenses/by/ $4.0 /)$.
Department of Natural Resources and Environmental Studies, National Dong Hwa University, Hualien 97401, Taiwan; mcsu@gms.ndhu.edu.tw

* Correspondence: clintlewis784@gmail.com; Tel.: +886-9-6547-3379

\begin{abstract}
Climate change is an existential threat to small island developing states. Policy coherence aims to create synergies and avoid conflicts between policies. Mainstreaming adaptation across multiple sectors and achieving greater coherence amongst policies is needed. The paper applies qualitative document analysis, content analysis, and expert interviews to examine the degree of coherence between climate-sensitive sector policies in framing climate change adaptation and the adaptation goals outlined in the national development plan and national climate change policies in St. Vincent and the Grenadines (SVG), Grenada, and Saint Lucia. The results indicate that adaptation is not fully integrated into the water, agriculture, coastal zone, and forestry policies. For example, while adaptation was explicitly addressed in Saint Lucia's water policy, it was not explicitly addressed in SVG's and Grenada's water policy. The results show that Saint Lucia has the highest coherence score (93.52) while St. Vincent and the Grenadines has the lowest (91.12). The optimal coherence score that can be possibly obtained is 147 , which indicates partial coherence in adaptation mainstreaming in sectoral policies. Expert interviews highlighted problems such as institutional arrangements, a silo approach, funding mechanisms, and policy implementation. Using the knowledge provided by the experts, a seven-step process is proposed to practically achieve policy coherence and operationalize the policies.
\end{abstract}

Keywords: adaptation; climate change; policy coherence; mainstreaming; Caribbean; SIDS

\section{Introduction}

Climate change is a daunting challenge for Small Island Developing States (SIDS). In the Caribbean, it is arguably the most severe challenge to the region's development aspirations. As climate change is projected to increase sea-level rise, increase the intensity of tropical and extra-tropical cyclones, increase temperature, and alter rainfall patterns in SIDS [1], careful adaptation planning is critical to their development. Climate change impacts occur alongside a changing socioeconomic and demographic landscape that integrate to affect development outcomes.

The Fifth Assessment Report of the Intergovernmental Panel on Climate Change (IPCC) highlighted human, terrestrial, and coastal systems as the three key sections for SIDS that are highly affected by climate change. The IPCC document illustrates a high degree of confidence for human and environmental systems experiencing the effects of climate change. Further, the report presents a very high degree of confidence for the rising of sea-levels. The high degree of confidence shown in the report also extends to the certainty of increased damage and loss during extreme weather events, increased coastal erosion, and further degradation of groundwater quality. The report also documents the existing effects on terrestrial systems, marine and coastal systems, water resources, human settlements, economies, and tourism.

SIDS are highly exposed to the impact of climate change. A significant amount of their population and infrastructural assets are located in areas exposed to climate hazards [2]. In the Caribbean, approximately seventy per cent of the population live in 
coastal cities, towns, and villages exposed to climate hazard [3]. SIDS's susceptibility to climate change is observed in the various sectors that are important to their national economies. SIDS are heavily dependent on climate-sensitive sectors such as agriculture, tourism, and fisheries. These sectors rely on good environmental conditions and are therefore affected by any adverse changes to the environment [4,5]. For example, tourism makes up more than fifty per cent of the national Gross Domestic Product (GDP) for tourism-dependent countries [6]. SIDS are also economically vulnerable to extreme weather events. Rapid onset events such as hurricanes cause an estimated USD 83 million worth of damage annually in the Caribbean [7]. With a small population, vulnerable economies, and limited resources, a single extreme weather event can cause damages and losses of nationally significant proportions $[8,9]$. For example, in 2017, Dominica reported economic losses and damages of USD 1.3 billion or $225 \%$ of their GDP as a result of the impacts of Hurricane Maria [10]. Meanwhile, Antigua and Barbuda reported estimated losses and damages of USD 222 million from the impacts of Hurricane Irma [11].

Policy coherence in climate change adaptation is essential for SIDS affected by climate change yet are heavily dependent upon the environment. The challenges associated with island development is exacerbated by climate change and adds to environmental insecurity [12], especially as these countries are economically dependent on climate-sensitive sectors. In the Caribbean region, on the backdrop of the inherent problems of managing and reducing the associated risk of natural disasters and promoting national development, the necessity to adapt to climate change augments the developmental challenges as the region struggles to adapt and build resilience to new risks. For SIDS, adaptation is an essential part of climate change response from a policy perspective. This is mainly because the projections shows that climate change will induce greater extreme weather events with more intensity and further diminish the conditions necessary for climate-sensitive sectors, which includes agriculture and tourism, to thrive [1].

For SIDS, adaptation equates to policies that enhance infrastructures for water resources, enhance coastal resilience to withstand seal-level rise and storm surges, implementation of early warning systems, climate-proofing infrastructure, the realization of marine protected areas, and the implementation of desalination plants and rainwater harvesting to improve water [13]. For example, in the Caribbean, the agriculture sector adaptation policies mainly include climate-smart techniques, developed irrigation systems, and climate-resilient crops and livestock. In the energy sector, adaptation entails finding alternative energy to replace fossil fuels with a regional expenditure in excess of USD 37 million [14].

Caribbean SIDS lack human capacity, sustainable financing, and technical resources to implement adaptation policies. Poor coordination between government departments also affects adsorptive capacity when finance is accessible [15]. Countries like St. Vincent and the Grenadines, Grenada, and Saint Lucia depend heavily on donor funding through projects to advance adaptation efforts. However, SIDS generally lack the necessary human and institutional capacity to access climate funding, for example, the Green Climate Fund. Therefore, policies are halted when the project cycle is completed. For example, after Grenada was devastated by Hurricane Ivan, the country acquired funding under its strategic program to build climate resilience. However, after the pilot project for climate change resilience ended, the government could not sustain that resilience project [16].

Policy coherence is essential as it promotes the effective use of resources, supports synergies between distinct policies and departments, and reduces overlaps by integrating sectoral objectives [17]. It is necessary as policy coherence requires the stakeholder's committed involvement from the conception to implementing the policy [18]. Huttunen et al. [19] showed that complementary policies in one sector are made ineffective by non-complementary policies, instruments, and practices in other sectors. It is thus essential to distinguish if distinct but complementary policies share collective goals and if they are contradictory to each other [20]. The obligation for policy coherence is even greater for SIDS because improved integration and 
cooperation will drastically cut down work duplicity and fragmentation between policies and departments and effectively use limited resources to accomplish collective goals [21].

Although there is global acknowledgement on the significance of mainstreaming adaptation in sectoral policies, it happens very infrequently in practice. Climate change and policy coherence studies reveal that not many have taken adaptation needs into consideration (e.g., [22-26]). Urwin and Jordan [27] found that climate change adaptation is rarely addressed in sectoral policies in the United Kingdom, while England et al. [28] established that sectoral policies and climate change policies are predominantly in Southern Africa geared towards disaster management planning instead of the focus being on adaptation.

Several studies are highlighted in the academic literature that uses different methodologies to analysis policy coherence. While Antwi-Agyei et al. [23] and England et al. [28] both used a qualitative document analysis (QDA) approach, Nilsson et al. [26] used a policy-analytical approach consisting of three steps: the inventory of policy objectives, the screening matrix, and an in-depth analysis of key interactions. However, the literature shows limited studies on policy coherence and adaptation in developing countries; more so, in SIDS, studies are rare, and that is the case of the Caribbean region. SIDS contribute less than one per cent of carbon emissions [4,29] but are highly vulnerable to its impacts. Policy-makers in the Caribbean region recognize the importance of climate change and are more frequently integrating adaptation and mitigation strategies into sectoral policies. However, lack of policy coherence is one of the critical factors hindering practical adaptation actions in the region [24].

Given the uniqueness of SIDS [1] and their lack of resilience to the impacts of climate change, several new climate change-related policies and sectoral policies within the climatesensitive sectors have been developed in a relatively short timeframe. Most of these policies have been developed through donor-funded initiatives. Hence, one has to ask if the policies are complementary with each other or contradict each other and create significant trade-offs. St. Vincent and the Grenadines (SVG), Grenada, and Saint Lucia are strongly dependent on climate-sensitive sectors such as agriculture and tourism. Therefore, examining the extent of coherence within these countries' climate change policy frameworks is essential.

This paper focuses on a region where academic literature on climate change adaptation studies is limited. It also focuses on a topic that is not highlighted in the region at the national level. The paper aims to assess the degree in which climate-sensitive sector policies are coherent with each other in framing adaptation in St. Vincent and the Grenadines, Grenada, and Saint Lucia. We analyzed the various climate change-related policies, development policy, and sectoral policies to answer the following questions:

(1) To what extent adaptation strategies are included in the water, agriculture, coastal zone, and forestry sector policies?

(2) What is the degree of policy coherence between the climate-sensitive sectors, climate change adaptation policies, and national development plans?

(3) How can policy coherence be practically achieved at the cross-sectoral level?

To this end, our analysis provides (1) a more comprehensive understanding of how the three countries integrate climate change adaptation in sectoral policies, (2) information on the issues that hinders the policy process from inception to implementation, and (3) practical steps to address the issues. The research is analyzed using document analysis and complemented with qualitative expert interview data. Both methods are critical in triangulating the data for a more robust and comprehensive research. We focus on the water, agriculture, coastal zone, and forestry sectors due to their climate-sensitive nature. The coastal zone is vital for tourism and fisheries, which are two important livelihoods in the region. In 2019, agriculture, forestry, fishing, and tourism altogether contributed 53.4\%, $45 \%$, and $60.7 \%$ to the Gross Domestic Product (GDP) of St. Vincent and the Grenadines, Saint Lucia, and Grenada, respectively [30-33] 


\section{Materials and Methods}

To analyze the degree of adaptation and policy coherence in SVG, Grenada, and Saint Lucia, QDA was used. Qualitative document analysis aids in the impartial analysis of documents [34] and gives a procedure that takes into consideration the meaning and significance of the text. The method utilizes subjective scoring criteria, which is validated by the use of expert interviews. The technique used in this research adheres to various steps (Table 1) to enhance the analysis's rigor and cohesion [23,34].

Table 1. Methodological technique applied to the research.

\begin{tabular}{ll}
\hline Methodological Steps & Description \\
\hline Setting criteria for selecting the documents & $\begin{array}{l}\text { Focus was placed on countries in the OECS with a complete compliment of } \\
\text { documents needed. }\end{array}$ \\
\hline Collecting the documents & $\begin{array}{l}\text { Internet search facilitated the collection of documents. Contact was made with } \\
\text { personnel from the respective countries to ascertain documents not found online. }\end{array}$ \\
\hline Analyzing the documents & $\begin{array}{l}\text { Content analysis technique founded on subjective scoring criteria was used to } \\
\text { evaluate coherence. }\end{array}$ \\
\hline Validating the documents & $\begin{array}{l}\text { Expert interviews were conducted from the public and private sectors in the } \\
\text { respective countries and from regional organizations as shown in the results. }\end{array}$ \\
\hline Finalizing the documents & Expert interviews were analyzed for common themes to inform the discussion. \\
\hline
\end{tabular}

In setting the research boundaries and the criteria for selecting documents (step 1), we considered all the countries within the Organization of the Eastern Caribbean States (OECS). From this, we focused on SVG, Grenada, and Saint Lucia because each country has a complete set of policies across the agriculture, water, coastal zone, and forestry sectors, including complete policies on climate change and national development plans (Table 2). These sectors were mainly targeted because of their integral role in determining adaptation actions. Though the energy and transportation sectors are also important, they primarily focused on climate change mitigation. Therefore, in the research we included them but ultimately decided to omit both sectors. Internet searches were conducted to locate the necessary documents online (step 2). Personal contact was made with personnel working in various ministries within the respective countries to ascertain unavailable documents online. The documents were analyzed (step 3) to establish whether climate change adaptation was being considered or not, how climate change adaptation is framed, and if adaptation was consistent with the different policies evaluated. The policies were assessed with the use of a type of content analysis method founded on subjective scoring criteria [34] to evaluate coherence (Table 3).

The content analysis steps incorporated four phases. In phase one, the sector policies (agriculture, water, forestry), climate change policies, and national development policies were evaluated for main strategies to five decisive themes: (i) water, (ii) agriculture, (iii) forestry, (iv) coastal zone, and (iv) climate change adaptation. As strategies for water, agriculture, forest, and coastal zone adaptation to climate change were recognized, we recorded the lengthy context in which they were found. This facilitated identifying keywords that included: irrigation, drought, disaster management, flood, food security, water security, watershed management, reforestation, coastal erosion, reef destruction, and habitat destruction.

Phase two entailed the use of keywords to analyze the sections of every policy in which they were found. This assessed the adaptation strategies for water, agriculture, coastal zone, and forest on the basis of the text in which they were inserted in the policy document, providing particular background circumstances and understanding into government intentions and main concerns within the respective countries. The keywords and strategies were grouped, synthesized, and entered into a table. This allowed me to compare the critical points in each sector's policies along with the national climate change policies 
and the national development plans. It provided the necessary information based on the context that was needed to guide expert interviews.

Table 2. Sample documents for qualitative document analysis.

\begin{tabular}{|c|c|c|c|}
\hline \multirow{2}{*}{ Policy Documents } & \multicolumn{3}{|l|}{ Country } \\
\hline & St. Vincent and the Grenadines & Grenada & Saint Lucia \\
\hline Water Policy & Draft water safety plan [35] & National Water Policy [36] & $\begin{array}{l}\text { Sectoral Adaptation Strategy and Action Plan } \\
\text { for the Water Sector, 2018-2028 [37] }\end{array}$ \\
\hline Agriculture policy & $\begin{array}{l}\text { National Agriculture, Fisheries and } \\
\text { Forestry Sector Development Plan, } \\
2017-2025 \text { [38] }\end{array}$ & $\begin{array}{l}\text { National Agriculture Plan, } \\
\text { 2015-2030 [39] }\end{array}$ & $\begin{array}{l}\text { Sectoral Adaptation Strategy and Action Plan } \\
\text { for the Agriculture Sector, 2018-2028 [40] }\end{array}$ \\
\hline Forestry policy & $\begin{array}{l}\text { National Agriculture, Fisheries and } \\
\text { Forestry Sector Development Plan, } \\
2017-2025[38]\end{array}$ & $\begin{array}{l}\text { Revised Forestry Policy for } \\
\text { Grenada, Carriacou and Petit } \\
\text { Martinique [41] }\end{array}$ & Forest Policy [42] \\
\hline Coastal Zone Policy & $\begin{array}{l}\text { National Ocean Policy and Action } \\
\text { Plan [43] }\end{array}$ & $\begin{array}{l}\text { Integrated Coastal Zone } \\
\text { Management Policy [44] }\end{array}$ & National Ocean Policy [45] \\
\hline $\begin{array}{l}\text { Nationally Determined } \\
\text { Contribution }\end{array}$ & $\begin{array}{l}\text { Intended Nationally Determined } \\
\text { Contribution [46] }\end{array}$ & $\begin{array}{l}\text { Second Nationally Determined } \\
\text { Contribution [47] }\end{array}$ & Nationally Determines Contribution [48] \\
\hline National Development Plan & $\begin{array}{l}\text { National Economic and Social } \\
\text { Development Plan, 2013-2025 [49] }\end{array}$ & $\begin{array}{l}\text { National Sustainable Development } \\
\text { Plan, 2020-2035 [50] }\end{array}$ & Medium-Term Development Strategic Plan [51] \\
\hline Climate Change Policy & $\begin{array}{l}\text { National Climate Change } \\
\text { Policy [52] }\end{array}$ & $\begin{array}{l}\text { National Climate Change Policy, } \\
\text { 2017-2021 [53] }\end{array}$ & Climate Change Adaptation Policy [54] \\
\hline National Adaptation Plan & National Adaptation Plan [55] & $\begin{array}{l}\text { National Climate Change } \\
\text { Adaptation Plan, 2017-2021 [56] }\end{array}$ & National Adaptation Plan, 2018-2028 [57] \\
\hline
\end{tabular}

Table 3. Scoring model to evaluate coherence.

\begin{tabular}{ll}
\hline \multicolumn{1}{c}{ Type of Coherence } & \multicolumn{1}{c}{ Description of Coherence } \\
\hline High coherence & $\begin{array}{l}\text { The policy greatly aligns with those of different sectoral policies. The policy allocates special } \\
\text { consideration to integration within different sectors that concerns adaptation. Contains many } \\
\text { detailed and integral activities. }\end{array}$ \\
\hline Partial coherence & $\begin{array}{l}\text { The policy supports other sectors. Lacks clarity on achieving its goals. Contains less plans and } \\
\text { activities. Lacks comprehensive detail. }\end{array}$ \\
\hline Limited coherence & The policy supports other sectors. No details of plans or activities provided. \\
\hline No coherence & The policy shows no evidence of alignment with other sectors. \\
\hline
\end{tabular}

Phase three included looking for keywords in the specific themes. The keywords helped to evaluate the degree to which the various policies referred to similar concerns, for example, how the water policy, agriculture policy, coastal zone policy, climate change policies, and national development plans all relate to forestry. A score from $0-3$, which was adopted from the academic literature $[23,28,58]$ was then assigned, indicating the coherence rank (Table 3) for each of the four search words. For example, in reference to the theme "climate change adaptation", Saint Lucia's water policy highlights water vulnerabilities to climate change. It supports several management plans, including river bank management, integrated water resources management, and water pipelines and infrastructure upgrades. Therefore, it attained a coherence score of 2.

Phase four assessed the level of coherence between policies corresponding to one another in the respective countries. It was done by calculating the average of the two values in phase three. For example, SVG's Water Policy's coherence in respect to its National Adaptation Plan is 1.58 (as the average coherence for the Water Policy is 0.75 and for the National Adaptation Plan is 2.4).

For the validation and finalization process (steps 4 and 5), expert interviews from the governmental and non-governmental sectors were conducted. We interviewed one expert each from the regional organizations, including the Inter-American Institute for Cooperation on Agriculture (IICA), Organization of Eastern Caribbean States (OECS), Caribbean Community Climate Change Center (CCCCC) and Caribbean Community (CARICOM). The experts interviewed from the sectors had to be the head of a climate change, environment and/or development portfolio in a national government ministry, department or agency or the head of a climate change, environment and/or development 
project under a national government ministry, department, or agency. Ten expert interviews were conducted with participants from SVG, seven from Saint Lucia, and five from Grenada. A total of twenty-six interviews were conducted. To guarantee that the identity of the experts remained anonymous, we did not include exact details on the portfolio of the experts interviewed. Interview transcripts were manually coded and analyzed according to sectoral themes and policy priority areas.

\section{Results}

\subsection{Adaptation Planning in Sectoral Policies and National Development Plans}

The sectoral policies for water, agriculture, forestry, and coastal zone and the national development plans for SVG, Grenada, and Saint Lucia were examined. While adaptation was addressed thoroughly in Saint Lucia's water policy, it was not explicitly addressed in SVG and Grenada's water policies [35,36]. For example, Saint Lucia's Sectoral Adaptation Strategy and Action Plan for the water sector states that, "The policy will offer guidance to decision-making processes related to climate change adaptation in Saint Lucia's water sector during the next ten years" [37]. Adaptation was explicitly addressed in the agriculture policies of both SVG and Grenada. For example, SVG's National Agriculture, Fisheries and Forestry Sector Development Plan strategic objectives plan on "strengthening the governance structures to enable disaster risk reduction and climate change adaptation" and "Investing in disaster risk reduction and climate change adaptation for resilient livelihoods and ecosystem health, with particular focus on smallholder and rural producers" [38]. Grenada's agriculture policy notes that, "there is a need to build climate resilience to avoid, prevent, or minimize climate change impacts on agriculture" [39]. It also states that, "the strategic objective addresses the adaptation component of climate change from a sustainable development perspective" [39]. Adaptation was not thoroughly addressed in the agriculture policy of Saint Lucia [40]. The forestry policies follow a similar trend to that of the water policies. Adaptation was explicitly addressed in Grenada's forestry policy, which is not the case in both forestry policies for SVG and Saint Lucia [38,41]. For example, Grenada's forestry policy states that, "it will manage forest resources to build climate change resilience by implementing appropriate climate change adaptation and mitigation actions" [41]. Climate change adaptation was also thoroughly addressed in the coastal zone policy for all three countries. The coastal zone policy in SVG states that,

"The conservation of coastal areas under threat from both natural phenomena such as tsunamis and hurricanes, and anthropogenic threats such as sea-level rise, saline encroachment and loss of shoreline due to erosion, is a priority. Understanding the impacts and effects of climate change and other stressors is key to maintaining a healthy environment. The information will assist in the sustainable use of the coasts and oceans". [43]

The goal of the policy is to "incorporate appropriate adaptation and resilience building strategies into sustainable development, conservation and governance actions" [43]. The adaptation measures outlined in the policy include the incorporation of adaptation and resilience building strategies to reduce risk of coastal hazards; the development and implementation of mechanisms for monitoring changing sea levels, currents, and sedimentation patters; and the development of coastal zone and shoreline management plans. The coastal zone policy for Grenada highlights the impacts of climate change on the sector and the impediments to build adaptive capacity. One of the main objectives of the policy is to "facilitate optimal conditions for ecosystem restoration, rehabilitation and recovery" [44], in which the government aims to monitor the impacts of extreme events on the coastal zone and monitor the coastal ecosystems and the effects of human activities. Another objective is to "prevent, reduce, or mitigate the discharge of pollutants into nearshore areas, that are derived from human activities within the coastal zone" [44], in which the government of Grenada aims to implement management activities to control and reduce pollution from watersheds which is then transmitted to the coast via rivers and estuaries, and to establish and enforce standards and guidelines for the disposal of waste water and 
other discharges from buildings, industries, domestic, and other activities into the coastal zone. Saint Lucia's coastal zone policy [45] highlights the importance of a ridge to reef approach, ecosystem-based approach to ensure that activities on land do not adversely impact the marine environment. This is along with coordination across planning and management of activities that may impact the marine area, as well as embedding social and environmental considerations within national policy development. The policy supports the Caribbean Challenge Initiative in protecting at least twenty per cent of coastal and marine areas by 2020. The policy focuses on the marine environment and biodiversity protection, surface water management and wastewater treatment and disposal, and coastal development. Some of the considerations for decision making mentioned in the policy include: understanding the state of the marine environment, and how human activity impacts upon it, with particular reference to sensitive habitats and species; aligning any coastal or marine spatial planning process with existing mechanisms by considering areas and features of importance for nature conservation and wider biodiversity in developing policies and locations for other marine activities, and in permitting new development; considering the impacts of land-based pollution and discharges to receiving coastal waters on human and ecosystem health, and on livelihoods; considering a precautionary and risk-based approach to ensure that activities and developments will be climate resilient, and not negatively impact upon coastal change; and considering ecosystem-based adaptation and interventions in all proposals for future development.

Adaptation was included explicitly in several sections of the national development plans for all three countries. All three countries recognize the importance of integrating climate change into the development plans, especially as the countries have witnessed the devastation of extreme weather events such as Hurricane Tomas in 2010 and Hurricanes Irma and Maria in 2017. St. Vincent and the Grenadine's national development plan stresses the importance of "improving physical infrastructure, preserving the environment and building resilience to climate change" [49] by focusing on reducing climate change impacts on the various sectors. Grenada's national development plans emphasize the importance of "strengthen institutional structures and arrangements to support coordination, mainstreaming, and implementation of climate change adaptation and mitigation actions, along with the systematic integration of climate change adaptation into development policies, plans, programs, projects, budgets, and processes" [50]. On the other hand, Saint Lucia's national development plan focuses on environmental management and infrastructure development by emphasizing the need to "develop adaptation measures for climate change" and "mainstreaming climate change adaptation in sectoral policies" [51].

\subsection{Sectoral Policy Coherence with Climate Change Policies and Development Plans}

The policy analysis conducted shows an extensive and varied range of water, agriculture, coastal zone, and forestry adaptation strategies in the three countries' policy documents (Table 4). The vast majority of adaptation strategies highlighted in the three countries' sectoral policies coincide with that in the NAP and NCCP, and to a lesser extent with the NDCs. In terms of the respective countries development plans, while the adaptation strategies are generally similar to those in the sectoral policies, the policy statements are coined to a more holistic developmental approach for which building climate change resilience is a significant component. The effects of climate change are expected to increase sea-level rise, reduce rainfall, and result in more extended dry periods and more intense tropical storms [1]. The trends identified in the agriculture, water, forestry, and coastal zone policies within the three countries show that their adaptation strategies consider extreme weather events, especially hurricanes, droughts, and floods. It also takes into consideration the long-term climate change trends for the region. The three countries' agricultural adaptation strategies include climate-smart agricultural practices, early warning systems, investments in water harvesting and irrigation schemes, and drought and flood-tolerant strains of grass for livestock. These strategies align with the climate projections for the region and, more specifically, longer dry seasons. The analysis shows that while some 
adaptation strategies can be termed as transformational adaptation, most of the strategies are of a more incremental approach to adaptation. One plausible explanation is the insufficient information on long-term climate data to inform adequate adaptation planning [59], the perceived cost of transformational actions [60] and/or a suite of institutional and behavioral barriers that tend to maintain existing resource systems and policies [61].

The results revealed that while long-term adaptation strategies were more diverse, the short-term event-based adaptation strategies was more predominantly featured that address issues of more immediate risk and disaster management need across the sectoral policies. For example, in terms of water management strategies, the most predominant were water conservation, rainwater harvesting, and disaster management. On the other hand, the long-term water management adaptation strategies include integrated water resource management, upgrading and improving pipelines and infrastructure, and constructing solar desalination plants. The most predominant agriculture adaptation strategies include climate-smart agricultural practices, early warning systems, and livestock management. Examples of long-term agricultural adaptation strategies include scientific research (soil and crop) and irrigation systems development. The most frequent adaptation strategies in the forestry sector include reforestation and watershed management. Examples of longterm forest adaptation strategies include forest diversification, protected areas management, and zoning practices.

The analysis conducted on climate change documents, including the national adaptation plan, national climate change policy, and nationally determined contributions, highlights concern about the increased intensity of hurricanes, the prolonged dry periods within recent years, and floods. All the documents from the three countries stressed the importance of flood and drought management. The policies support various water, agriculture, coastal zone, and forest strategies, including the implementation of early warning systems, development of desalination plants, and forest management to build resilience within the sectors and strengthen food and water security.

Analyzing the degree of policy coherence on climate change adaptation among the three countries, the analysis reveals that Grenada has the best complementary mix of policies based on the level of coherence, followed by St. Vincent and the Grenadines. At the same time, Saint Lucia exhibited the least coherent set of policies (Table 5). A closer look at the results shows that the National Adaptation Plans for all three countries consist of the most coherence compared to the other documents examined. On the other hand, the water policy for St. Vincent and the Grenadines, the water and forestry policies for Grenada, and the forestry policy for Saint Lucia provide the least coherence when compared to the other documents.

Although Saint Lucia (93.52) scores slightly higher than Grenada (92.89) and St. Vincent and the Grenadines (91.12), the optimal coherence score that can be possibly obtained in the matrix is 147. Our findings show that the level of mainstreaming adaptation into sectoral policies remains partial. To this end, the barriers to and drivers for attaining more mainstreamed policies for improved adaptation were a primary focus of the expert interviews. The expert interviews were conducted to validate and discuss the trends shown in Tables 4 and 5.

\subsection{Expert Interview Verification}

Interviews with government and non-government officials in the respective countries discussed the findings and scores in Tables 4 and 5. They also discussed the challenges to achieve more mainstreamed climate change adaptation into the sectoral policies. Each country has developed their climate change policies within the last 10 years. While there are some common trends in the experts' responses, there are some experiences which are different in each of the respective cases. 
Table 4. Summarized Table Showing Coherence between Policies Aim at Addressing Climate Change through Adaptation Measures in SVG, Grenada and Saint Lucia.

\begin{tabular}{|c|c|c|c|c|c|c|c|c|}
\hline Country & Water Policy & Agriculture Policy & Forestry Policy & Coastal Zone Policy & $\begin{array}{l}\text { National } \\
\text { Development Plan }\end{array}$ & $\begin{array}{l}\text { National Climate } \\
\text { Change Policy }\end{array}$ & $\begin{array}{l}\text { National } \\
\text { Adaptation Plan }\end{array}$ & $\begin{array}{l}\text { Nationally } \\
\text { Determined } \\
\text { Contribution }\end{array}$ \\
\hline Water & N/A & $\begin{array}{l}\text { (2) Recognizes } \\
\text { alignment between } \\
\text { water and agriculture. } \\
\text { Supports rainwater } \\
\text { harvesting and } \\
\text { irrigation initiatives, } \\
\text { including other plans. }\end{array}$ & $\begin{array}{l}\text { (2) Highlights } \\
\text { alignment between } \\
\text { water and forestry. } \\
\text { Plans include soil } \\
\text { conservation and } \\
\text { riverbank stabilization, } \\
\text { and watershed } \\
\text { management. } \\
\text { Lacks details. }\end{array}$ & $\begin{array}{l}\text { (0) No alignment } \\
\text { between water and } \\
\text { coastal zone outlined in } \\
\text { the policy. }\end{array}$ & $\begin{array}{l}\text { (2) Supports plans to } \\
\text { protect and manage } \\
\text { water resources such as } \\
\text { stop farming and other } \\
\text { human activities } \\
\text { around water } \\
\text { catchments. } \\
\text { Lacks details. }\end{array}$ & $\begin{array}{l}\text { (2) Recognizes water } \\
\text { quantity and quality as } \\
\text { an issue of concern. } \\
\text { Few plans for water } \\
\text { management. } \\
\text { Lacks details. }\end{array}$ & $\begin{array}{l}\text { (2) Indicates } \\
\text { ramifications on water } \\
\text { security, including } \\
\text { droughts and floods. } \\
\text { Some adaptation plans } \\
\text { but lack details. }\end{array}$ & $\begin{array}{l}\text { (1) Highlights the } \\
\text { threat of climate change } \\
\text { on the water sector. } \\
\text { Actions include rooftop } \\
\text { rainwater harvesting } \\
\text { system. Lacks details. }\end{array}$ \\
\hline Agriculture & $\begin{array}{l}\text { (1) Recognizes the role } \\
\text { of agriculture in water } \\
\text { management. } \\
\text { No details. }\end{array}$ & N/A & $\begin{array}{l}\text { (2) Highlights } \\
\text { alignment between } \\
\text { agriculture and forestry. } \\
\text { Plans include } \\
\text { increasing access to } \\
\text { suitable lands for } \\
\text { agriculture and soil } \\
\text { conservation. } \\
\text { Lacks details. }\end{array}$ & $\begin{array}{l}\text { (1) Recognizes } \\
\text { alignment between } \\
\text { agriculture and coastal } \\
\text { zone. Plans include } \\
\text { building awareness to } \\
\text { farmers on the effects } \\
\text { of bad agricultural } \\
\text { practices on the coastal } \\
\text { zone. Lacks details }\end{array}$ & $\begin{array}{l}\text { (2) Recognizes food } \\
\text { security as an issue of } \\
\text { concern. Supports the } \\
\text { irrigation and water } \\
\text { harvesting programs, } \\
\text { among other plans. } \\
\text { Lack details. }\end{array}$ & $\begin{array}{l}\text { (2) Shows susceptibility } \\
\text { of rainfed agricultural } \\
\text { practices. Includes } \\
\text { several climate-smart } \\
\text { agricultural and land } \\
\text { use plans but } \\
\text { lacks details. }\end{array}$ & $\begin{array}{l}\text { (2) Highlights } \\
\text { vulnerability of rainfed } \\
\text { agriculture to droughts, } \\
\text { uneven rainfall, and } \\
\text { natural disaster. Details } \\
\text { several plans } \\
\text { and activities. }\end{array}$ & $\begin{array}{l}\text { (1) Highlights } \\
\text { susceptibility of the } \\
\text { agricultural sector to } \\
\text { climate change. Actions } \\
\text { include a national plan } \\
\text { for dealing with food } \\
\text { security. Lacks details. }\end{array}$ \\
\hline Forestry & $\begin{array}{l}\text { (1) Supports integrated } \\
\text { watershed } \\
\text { management. } \\
\text { No details. }\end{array}$ & $\begin{array}{l}\text { (2) Recognizes the link } \\
\text { between forestry and } \\
\text { agriculture. Supports } \\
\text { agro-forestry and } \\
\text { reforestation programs. } \\
\text { Lacks details. }\end{array}$ & $\mathrm{N} / \mathrm{A}$ & $\begin{array}{l}\text { (2) Recognizes the link } \\
\text { between forest and } \\
\text { coastal zone. Plans } \\
\text { include restoring } \\
\text { mangrove ecosystem. } \\
\text { Lacks details. }\end{array}$ & $\begin{array}{l}\text { (1) Supports } \\
\text { reforestation and } \\
\text { integrated watershed } \\
\text { management programs. } \\
\text { No details. }\end{array}$ & $\begin{array}{l}\text { (2) Highlights the } \\
\text { importance of forest. } \\
\text { Plans include } \\
\text { reforestation, 'ridge to } \\
\text { reef' and other } \\
\text { ecosystem-based } \\
\text { approaches, and } \\
\text { integrated water- } \\
\text { shed management. }\end{array}$ & $\begin{array}{l}\text { (2) Supports and details } \\
\text { reforestation and } \\
\text { watershed } \\
\text { management programs } \\
\text { and tree-planting } \\
\text { programs in } \\
\text { collaboration with } \\
\text { schools and } \\
\text { communities. }\end{array}$ & $\begin{array}{l}\text { (1) Supports } \\
\text { sustainable land } \\
\text { management to address } \\
\text { concerns of rapid } \\
\text { deforestation. } \\
\text { No details }\end{array}$ \\
\hline Coastal Zone & $\begin{array}{l}\text { (0) No linkagesbetween } \\
\text { water and coastal area } \\
\text { outlined in the policy. }\end{array}$ & $\begin{array}{l}\text { (0) No linkages } \\
\text { between agriculture } \\
\text { and coastal area } \\
\text { outlined in the policy. }\end{array}$ & $\begin{array}{l}\text { (0) No linkages } \\
\text { between forestry and } \\
\text { coastal area outlined in } \\
\text { the policy. }\end{array}$ & N/A & $\begin{array}{l}\text { (1) Recognizes the } \\
\text { importance of coastal } \\
\text { zones for development. } \\
\text { No details. }\end{array}$ & $\begin{array}{l}\text { (3) Highlights the } \\
\text { vulnerability of coastal } \\
\text { areas to climate change. } \\
\text { Numerous detailed } \\
\text { plans include updating } \\
\text { regulations on coastal } \\
\text { zone to include } \\
\text { building codes and } \\
\text { zoning. Climate proof } \\
\text { coastal infrastructure } \\
\text { using ecosystem-based } \\
\text { solutions, restoration of } \\
\text { reefs and mangroves. } \\
\text { Construction of } \\
\text { revetments and sea } \\
\text { wall defense. }\end{array}$ & $\begin{array}{l}\text { (3) Highlights the } \\
\text { vulnerability of coastal } \\
\text { areas to climate change } \\
\text { adaptation. Numerous } \\
\text { detailed plans include } \\
\text { update building codes } \\
\text { to avoid discharges of } \\
\text { wastewater in the coast } \\
\text { to protect reefs. Coastal } \\
\text { zone impact } \\
\text { modeling.Coastal } \\
\text { defense project. }\end{array}$ & $\begin{array}{l}\text { (3) shows the } \\
\text { susceptibility of coastal } \\
\text { areas to the impacts of } \\
\text { climate change. } \\
\text { detailed plans include } \\
\text { protecting } 20 \% \text { of its } \\
\text { near shore marine and } \\
\text { coastal resources by } \\
2020 \text {. Coastal } \\
\text { protection projects to } \\
\text { halt beach and cliff } \\
\text { erosion, stabilize the } \\
\text { shoreline and restore } \\
\text { beach and near-shore } \\
\text { reef. Sans Souci coastal } \\
\text { defense project. }\end{array}$ \\
\hline
\end{tabular}


Table 4. Cont.

\begin{tabular}{|c|c|c|c|c|c|c|c|c|}
\hline Country & Water Policy & Agriculture Policy & Forestry Policy & Coastal Zone Policy & $\begin{array}{l}\text { National } \\
\text { Development Plan }\end{array}$ & $\begin{array}{l}\text { National Climate } \\
\text { Change Policy }\end{array}$ & $\begin{array}{l}\text { National } \\
\text { Adaptation Plan }\end{array}$ & $\begin{array}{l}\text { Nationally } \\
\text { Determined } \\
\text { Contribution }\end{array}$ \\
\hline $\begin{array}{l}\text { Climate change } \\
\text { adaptation }\end{array}$ & $\begin{array}{l}\text { (1) Indicates plans to } \\
\text { enhance water security } \\
\text { and quality } \\
\text { management. } \\
\text { No details. }\end{array}$ & $\begin{array}{l}\text { (2) The policy } \\
\text { recognizes climate } \\
\text { change. Advocates } \\
\text { several plans such as } \\
\text { smart agriculture, } \\
\text { importation of drought } \\
\text { and flood-resistant } \\
\text { strains of grass for } \\
\text { livestock farm, and } \\
\text { farm irrigation } \\
\text { and water } \\
\text { harvesting projects. }\end{array}$ & $\begin{array}{l}\text { (1) Supports } \\
\text { sustainable forest } \\
\text { management to } \\
\text { alleviate the impacts of } \\
\text { climate change. } \\
\text { No details. }\end{array}$ & $\begin{array}{l}\text { (3) Recognizes climate } \\
\text { change potential } \\
\text { impacts on the coastal } \\
\text { areas. Numerous } \\
\text { detailed plans include } \\
\text { developing marine } \\
\text { protected areas, } \\
\text { developing and } \\
\text { implementing } \\
\text { mechanisms for } \\
\text { monitoring changing } \\
\text { sea levels, } \\
\text { implementing early } \\
\text { warning systems. }\end{array}$ & $\begin{array}{l}\text { (2) Highlights the } \\
\text { climate change } \\
\text { concerns on the } \\
\text { country's development. } \\
\text { Outlines various plans } \\
\text { include initiative for an } \\
\text { effective hazard } \\
\text { modelling system, } \\
\text { building resilience at } \\
\text { the community level, } \\
\text { and capacity needs } \\
\text { assessment. } \\
\text { Lacks details. }\end{array}$ & $\begin{array}{l}\text { (3) Details climate } \\
\text { change impacts to and } \\
\text { vulnerabilities of the } \\
\text { sectors. Includes } \\
\text { several detailed plans } \\
\text { for each sector such as } \\
\text { early warning systems, } \\
\text { smart agriculture, } \\
\text { programs of } \\
\text { reforestation and } \\
\text { agro-forestry, rainwater } \\
\text { harvesting systems, } \\
\text { wastewater recycling. }\end{array}$ & $\begin{array}{l}\text { (3) Details the impacts } \\
\text { of climate change and } \\
\text { how it affects the } \\
\text { sectors and livelihood. } \\
\text { Includes detailed } \\
\text { strategic plans and } \\
\text { activities such as } \\
\text { watershed } \\
\text { management, } \\
\text { increasing water } \\
\text { storage capacity, } \\
\text { implementation of solar } \\
\text { desalination plants in } \\
\text { the Grenadines, and } \\
\text { early warning } \\
\text { system initiatives. }\end{array}$ & $\begin{array}{l}\text { (2) Recognizes the } \\
\text { impacts of climate } \\
\text { change across the } \\
\text { country. Includes some } \\
\text { plans such as climate } \\
\text { vulnerability risk } \\
\text { assessment and risk } \\
\text { reduction and } \\
\text { framework for } \\
\text { strengthening existing } \\
\text { policy but lacks details. }\end{array}$ \\
\hline mean & 0.75 & 1.5 & 1.25 & 1.5 & 1.6 & 2.4 & 2.4 & 1.6 \\
\hline \multicolumn{9}{|c|}{ (b) Summarized Table Showing Coherence between Policies Aim at Addressing Climate Change through Adaptation Measures in Grenada } \\
\hline Country & Water Policy & Agriculture Policy & Forestry Policy & Coastal Zone Policy & $\begin{array}{l}\text { National } \\
\text { Development Plan }\end{array}$ & $\begin{array}{l}\text { National Climate } \\
\text { Change Policy }\end{array}$ & $\begin{array}{l}\text { National } \\
\text { Adaptation Plan }\end{array}$ & $\begin{array}{l}\text { Nationally } \\
\text { Determined } \\
\text { Contribution }\end{array}$ \\
\hline Water & $\mathrm{N} / \mathrm{A}$ & $\begin{array}{l}\text { (2) Recognizes linkage } \\
\text { between water and } \\
\text { agriculture. Promotes } \\
\text { water management and } \\
\text { conservation measures } \\
\text { including terracing, } \\
\text { rainwater harvesting } \\
\text { system for storage and } \\
\text { irrigation initiatives } \\
\text { such as drip irrigation. } \\
\text { Lacks details. }\end{array}$ & $\begin{array}{l}\text { (1) Recognizes the link } \\
\text { between water and } \\
\text { forestry. Supports } \\
\text { improved watershed } \\
\text { management. } \\
\text { No details. }\end{array}$ & $\begin{array}{l}\text { (2) Recognizes the link } \\
\text { between water and } \\
\text { coastal zone. Plans } \\
\text { include implementing } \\
\text { activities to control and } \\
\text { reduce pollution from } \\
\text { watersheds which ends } \\
\text { up in the coast. } \\
\text { Lacks details. }\end{array}$ & $\begin{array}{l}\text { (2) Supports plans to } \\
\text { protect and restore } \\
\text { water-related } \\
\text { ecosystems, promotes } \\
\text { increase investments in } \\
\text { rainwater harvesting } \\
\text { and desalination plants, } \\
\text { and increase storage, } \\
\text { distribution and use of } \\
\text { untreated water for } \\
\text { non-consumption } \\
\text { activities. Lacks details. }\end{array}$ & $\begin{array}{l}\text { (2) Recognizes } \\
\text { vulnerabilities of the } \\
\text { water sector. Plans } \\
\text { include reducing water } \\
\text { outage times during } \\
\text { flooding and droughts } \\
\text { and increase usage of } \\
\text { water conservation/ } \\
\text { efficiency measures. } \\
\text { Lacks details. }\end{array}$ & $\begin{array}{l}\text { (3) Indicates } \\
\text { vulnerabilities on water } \\
\text { security including } \\
\text { droughts and floods. } \\
\text { Detailed plans include } \\
\text { developing water } \\
\text { balances for major } \\
\text { watersheds, increase } \\
\text { surface storage and } \\
\text { improve the } \\
\text { distribution system, } \\
\text { and implement } \\
\text { water resources } \\
\text { investment programs. }\end{array}$ & $\begin{array}{l}\text { (1) Highlights the } \\
\text { threat of climate change } \\
\text { on the water sector. } \\
\text { No details. }\end{array}$ \\
\hline
\end{tabular}


Table 4. Cont.

\begin{tabular}{|c|c|c|c|c|c|c|c|c|}
\hline Country & Water Policy & Agriculture Policy & Forestry Policy & Coastal Zone Policy & $\begin{array}{l}\text { National } \\
\text { Development Plan }\end{array}$ & $\begin{array}{l}\text { National Climate } \\
\text { Change Policy }\end{array}$ & $\begin{array}{l}\text { National } \\
\text { Adaptation Plan }\end{array}$ & $\begin{array}{l}\text { Nationally } \\
\text { Determined } \\
\text { Contribution }\end{array}$ \\
\hline Agriculture & $\begin{array}{l}\text { (1) Recognizes the link } \\
\text { between agriculture } \\
\text { and water. Support the } \\
\text { provision of water for } \\
\text { smart agriculture but } \\
\text { no plans on how it will } \\
\text { be achieved. }\end{array}$ & $\mathrm{N} / \mathrm{A}$ & $\begin{array}{l}\text { (0) No reference to } \\
\text { agriculture. No } \\
\text { plans provided. }\end{array}$ & $\begin{array}{l}\text { (2) Recognizes the link } \\
\text { between agriculture } \\
\text { and coastal zone. Plans } \\
\text { include implementing } \\
\text { programs to reduce } \\
\text { agriculture land-based } \\
\text { pollution, } \\
\text { climate-smart } \\
\text { agriculture techniques. } \\
\text { Lacks details. }\end{array}$ & $\begin{array}{l}\text { (2) Recognizes food } \\
\text { security as an issue of } \\
\text { concern. Supports } \\
\text { climate-smart } \\
\text { agricultural practices, } \\
\text { which includes } \\
\text { improved irrigation } \\
\text { practices. Lacks details. }\end{array}$ & $\begin{array}{l}\text { (3) Highlights } \\
\text { vulnerabilities of } \\
\text { agriculture and food } \\
\text { security. Detailed plans } \\
\text { include establishing } \\
\text { four climate-smart } \\
\text { agriculture } \\
\text { demonstration sites } \\
\text { and agriculture officers } \\
\text { trained to advise } \\
\text { farmers on how } \\
\text { to implement } \\
\text { climate-smart practices. }\end{array}$ & $\begin{array}{l}\text { (3) Highlights } \\
\text { vulnerabilities in food } \\
\text { security. Detailed plans } \\
\text { include capacity } \\
\text { building to implement } \\
\text { climate-smart } \\
\text { agricultural practices } \\
\text { and establish four } \\
\text { climate-smart } \\
\text { agriculture } \\
\text { demonstration sites. }\end{array}$ & $\begin{array}{l}\text { (1) Highlights the } \\
\text { threat of climate change } \\
\text { on the agriculture } \\
\text { sector. No details. }\end{array}$ \\
\hline Forestry & $\begin{array}{l}\text { (1) Recognizes the link } \\
\text { between forestry and } \\
\text { water. Supports } \\
\text { integrated watershed } \\
\text { management. } \\
\text { No details. }\end{array}$ & $\begin{array}{l}\text { (2) Recognizes the link } \\
\text { between forestry and } \\
\text { agriculture. Plans } \\
\text { include conservation of } \\
\text { forestry protected areas, } \\
\text { agro-forestry, and } \\
\text { public awareness } \\
\text { programs. } \\
\text { Lacks details. }\end{array}$ & N/A & $\begin{array}{l}\text { (1) Recognizes the } \\
\text { importance of wetland } \\
\text { forest to coastal zone. } \\
\text { Plans include } \\
\text { mangrove restoration, } \\
\text { building awareness. } \\
\text { No details. }\end{array}$ & $\begin{array}{l}\text { (1) Recognizes the } \\
\text { importance of forestry } \\
\text { to national } \\
\text { development. Supports } \\
\text { integrated forest } \\
\text { management. } \\
\text { No details. }\end{array}$ & $\begin{array}{l}\text { (1) Recognizes the } \\
\text { importance of forest. } \\
\text { Supports reforestation } \\
\text { activities. No details. }\end{array}$ & $\begin{array}{l}\text { (1) Recognizes the } \\
\text { importance of forest. } \\
\text { Supports the } \\
\text { implementation of a } \\
\text { reforestation program. } \\
\text { No details. }\end{array}$ & $\begin{array}{l}\text { (1) Recognizes the } \\
\text { importance of forest. } \\
\text { Supports reforestation } \\
\text { activities. No details. }\end{array}$ \\
\hline Coastal Zone & $\begin{array}{l}\text { (2) Recognizes the link } \\
\text { between coastal zone } \\
\text { and water. Implement } \\
\text { activities to } \\
\text { prevent/control the } \\
\text { intrusion of salt water } \\
\text { into aquifers. } \\
\text { Lacks details. }\end{array}$ & $\begin{array}{l}\text { (0) No linkages } \\
\text { between coastal zone } \\
\text { and agriculture } \\
\text { outlined in the policy. }\end{array}$ & $\begin{array}{l}\text { (1) Recognizes the link } \\
\text { between coastal zone } \\
\text { and forestry. Plans } \\
\text { include implementing } \\
\text { program for mangrove } \\
\text { ecosystem restoration. } \\
\text { No details. }\end{array}$ & N/A & $\begin{array}{l}\text { (2) Recognizes the } \\
\text { importance of coastal } \\
\text { zone to national } \\
\text { development. Plans } \\
\text { include early warning } \\
\text { systems, developing } \\
\text { marine protected areas, } \\
\text { mangrove restoration. } \\
\text { Lacks details. }\end{array}$ & $\begin{array}{l}\text { (1) Recognizes the } \\
\text { importance of coastal } \\
\text { zone. Supports } \\
\text { mangrove restoration } \\
\text { and marine protected } \\
\text { areas. No details. }\end{array}$ & $\begin{array}{l}\text { (2) Recognizes the } \\
\text { importance of coastal } \\
\text { zone. Plans include } \\
\text { strengthening technical } \\
\text { capacity, coastal } \\
\text { engineering, coastal } \\
\text { vegetation. } \\
\text { Lacks details. }\end{array}$ & $\begin{array}{l}\text { (1) Recognizes the } \\
\text { importance of coastal } \\
\text { zone. Highlights the } \\
\text { need for hard and soft } \\
\text { coastal engineering. } \\
\text { No details. }\end{array}$ \\
\hline
\end{tabular}


Table 4. Cont.

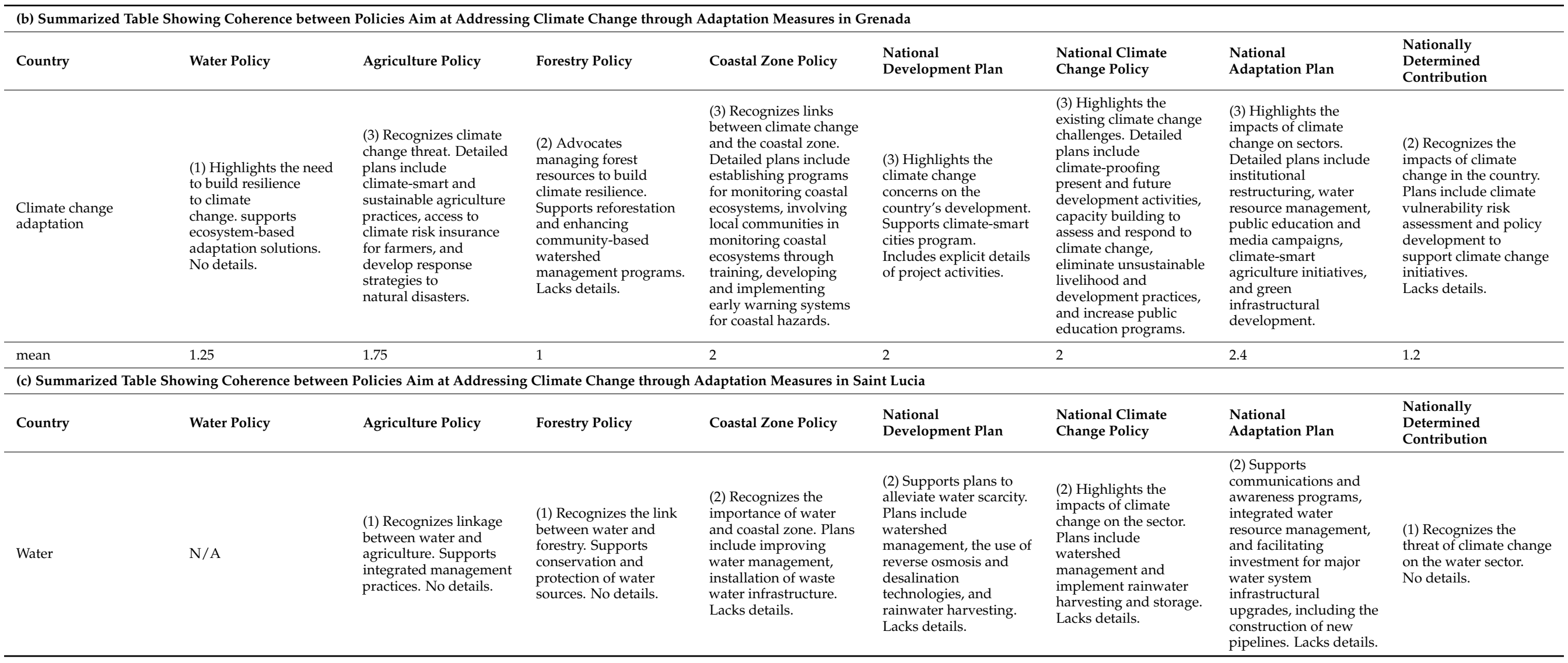


Table 4. Cont.

\begin{tabular}{|c|c|c|c|c|c|c|c|c|}
\hline Country & Water Policy & Agriculture Policy & Forestry Policy & Coastal Zone Policy & $\begin{array}{l}\text { National } \\
\text { Development Plan }\end{array}$ & $\begin{array}{l}\text { National Climate } \\
\text { Change Policy }\end{array}$ & $\begin{array}{l}\text { National } \\
\text { Adaptation Plan }\end{array}$ & $\begin{array}{l}\text { Nationally } \\
\text { Determined } \\
\text { Contribution }\end{array}$ \\
\hline Agriculture & $\begin{array}{l}\text { (2) Recognizes the link } \\
\text { between water and } \\
\text { agriculture. Plans } \\
\text { include improving } \\
\text { farm drainage } \\
\text { infrastructure, extend } \\
\text { drip irrigation systems, } \\
\text { and demonstration } \\
\text { plots to demonstrate } \\
\text { climate-smart farming } \\
\text { techniques. } \\
\text { Lacks details. }\end{array}$ & N/A & $\begin{array}{l}(0) \text { No reference to } \\
\text { agriculture. No plans } \\
\text { provided. }\end{array}$ & $\begin{array}{l}\text { (2) Recognizes the } \\
\text { impacts of poor } \\
\text { agriculture practices on } \\
\text { the coastal zone. Plans } \\
\text { include awareness, } \\
\text { climate-smart farming } \\
\text { techniques. } \\
\text { Lacks details. }\end{array}$ & $\begin{array}{l}\text { (2) Recognizes food } \\
\text { security as an issue of } \\
\text { concern. Supports } \\
\text { climate-smart } \\
\text { agricultural practices } \\
\text { programs, } \\
\text { ecosystem-based } \\
\text { adaptation approach, } \\
\text { and capacity building } \\
\text { for farmers. } \\
\text { Lacks details. }\end{array}$ & $\begin{array}{l}\text { (1) Highlights the } \\
\text { impacts on agriculture } \\
\text { and food security. Plans } \\
\text { include conservation } \\
\text { and management. } \\
\text { No details. }\end{array}$ & $\begin{array}{l}\text { (3) Supports the } \\
\text { extension of drip } \\
\text { irrigation use plans, } \\
\text { climate-smart farming } \\
\text { techniques, training for } \\
\text { farmers to use } \\
\text { technology, } \\
\text { climate-resilient crops } \\
\text { and animals initiatives, } \\
\text { importation of heat and } \\
\text { drought tolerant crop } \\
\text { programs, watershed } \\
\text { management, construct } \\
\text { climate-resilient } \\
\text { infrastructure to } \\
\text { improve water supply } \\
\text { and storage on } \\
\text { the farm. }\end{array}$ & $\begin{array}{l}\text { (1) Highlights the } \\
\text { threat of climate change } \\
\text { on the agriculture } \\
\text { sector. Supports } \\
\text { building resilience. } \\
\text { No details. }\end{array}$ \\
\hline Forestry & $\begin{array}{l}\text { (2) Supports } \\
\text { reforestation program, } \\
\text { integrated forest } \\
\text { management, and } \\
\text { sustainable } \\
\text { forest-based livelihood. } \\
\text { Lacks details. }\end{array}$ & $\begin{array}{l}\text { (1) Recognizes linkage } \\
\text { between forestry and } \\
\text { agriculture. Supports } \\
\text { land-use zoning and } \\
\text { reforestation. } \\
\text { No details. }\end{array}$ & N/A & $\begin{array}{l}\text { (2) Recognizes the } \\
\text { importance of forest } \\
\text { especially wetland } \\
\text { forest to coastal zone. } \\
\text { Plans include } \\
\text { mangrove } \\
\text { rehabilitation, marine } \\
\text { protected areas. } \\
\text { Lack details. }\end{array}$ & $\begin{array}{l}\text { (2) Highlights the } \\
\text { importance of the forest } \\
\text { to development. } \\
\text { Supports integrated } \\
\text { watershed } \\
\text { management and } \\
\text { reforestation programs. } \\
\text { Lacks details. }\end{array}$ & $\begin{array}{l}\text { (1) Recognizes the } \\
\text { importance of the forest } \\
\text { to alleviate the impacts } \\
\text { of climate change. } \\
\text { No details }\end{array}$ & $\begin{array}{l}\text { (2) Supports the } \\
\text { expansion of } \\
\text { reforestation programs, } \\
\text { promote new and } \\
\text { expand sustainable } \\
\text { forest-based livelihood } \\
\text { opportunities, and } \\
\text { include green spaces in } \\
\text { urban planning. } \\
\text { Lacks details. }\end{array}$ & $\begin{array}{l}\text { (1) Recognizes the } \\
\text { importance of forest. } \\
\text { Supports reforestation } \\
\text { activities. No details. }\end{array}$ \\
\hline
\end{tabular}


Table 4. Cont.

\begin{tabular}{|c|c|c|c|c|c|c|c|c|}
\hline Country & Water Policy & Agriculture Policy & Forestry Policy & Coastal Zone Policy & $\begin{array}{l}\text { National } \\
\text { Development Plan }\end{array}$ & $\begin{array}{l}\text { National Climate } \\
\text { Change Policy }\end{array}$ & $\begin{array}{l}\text { National } \\
\text { Adaptation Plan }\end{array}$ & $\begin{array}{l}\text { Nationally } \\
\text { Determined } \\
\text { Contribution }\end{array}$ \\
\hline Coastal Zone & $\begin{array}{l}\text { (1) Recognizes the link } \\
\text { between coastal zone } \\
\text { and water. Plans } \\
\text { include conducting } \\
\text { awareness raising } \\
\text { campaigns. No details. }\end{array}$ & $\begin{array}{l}\text { (1) Recognizes link } \\
\text { between coastal zone } \\
\text { and agriculture. } \\
\text { Highlights establishing } \\
\text { integrated coastal } \\
\text { management. } \\
\text { No details. }\end{array}$ & $\begin{array}{l}\text { (2) Recognizes the link } \\
\text { between coastal zone } \\
\text { and forestry. Plans } \\
\text { include enhancing } \\
\text { community-based } \\
\text { watershed } \\
\text { management to reduce } \\
\text { the incidence of excess } \\
\text { run-off and pollution } \\
\text { on coastal and marine } \\
\text { resources, protecting } \\
\text { mangrove ecosystem. } \\
\text { Lacks details. }\end{array}$ & N/A & $\begin{array}{l}\text { (2) Highlights the } \\
\text { importance of coastal } \\
\text { zones. Plans include } \\
\text { stronger regulations for } \\
\text { coastal area } \\
\text { developments and } \\
\text { partnership with local } \\
\text { private sector operators } \\
\text { to develop local coastal } \\
\text { sustainability projects. } \\
\text { Lacks details. }\end{array}$ & $\begin{array}{l}\text { (2) Highlights the } \\
\text { vulnerability of coastal } \\
\text { zone to climate change. } \\
\text { Plans include } \\
\text { establishing integrated } \\
\text { coastal management } \\
\text { and adaptation } \\
\text { measures to increase } \\
\text { the resilience of coastal } \\
\text { systems, communities, } \\
\text { critical infrastructure, } \\
\text { and economic activities. } \\
\text { Lacks details. }\end{array}$ & $\begin{array}{l}\text { (2) Recognizes the } \\
\text { country's vulnerable } \\
\text { coastal zone. Plans } \\
\text { include modeling and } \\
\text { mapping coastal } \\
\text { flooding under } \\
\text { sea-level rise to be } \\
\text { assessed and updated } \\
\text { periodically, } \\
\text { maintaining existing } \\
\text { vegetative buffers such } \\
\text { as mangroves, coastal } \\
\text { vegetation, river } \\
\text { banks-through } \\
\text { regulations and } \\
\text { enforcement. Develops } \\
\text { hazard and risk maps. } \\
\text { Lacks details. }\end{array}$ & $\begin{array}{l}\text { (2) Highlights the } \\
\text { threat of climate change } \\
\text { to the coastal zone. } \\
\text { Plans include } \\
\text { establishing the basis } \\
\text { for improving beach } \\
\text { management and } \\
\text { coastal erosion control } \\
\text { under changing climate } \\
\text { conditions, evaluation } \\
\text { of shoreline } \\
\text { stabilization } \\
\text { technologies in selected } \\
\text { vulnerable coastal } \\
\text { areas. Lacks details. }\end{array}$ \\
\hline $\begin{array}{l}\text { Climate change } \\
\text { adaptation }\end{array}$ & $\begin{array}{l}\text { (2) Highlights } \\
\text { vulnerabilities of water } \\
\text { to the impacts of } \\
\text { climate change. Plans } \\
\text { include riverbank } \\
\text { management, } \\
\text { Integrated Water } \\
\text { Resources } \\
\text { Management, and } \\
\text { water pipelines and } \\
\text { infrastructure upgrades. } \\
\text { Lacks details. }\end{array}$ & $\begin{array}{l}\text { (1) Highlights threats to } \\
\text { agriculture and food } \\
\text { security. Supports } \\
\text { conservation and land } \\
\text { management practices. } \\
\text { No details. }\end{array}$ & $\begin{array}{l}\text { (1) Recognizes } \\
\text { vulnerabilities of forest } \\
\text { to climate change. } \\
\text { Supports reforestation. } \\
\text { No details. }\end{array}$ & $\begin{array}{l}\text { (2) Recognizes the } \\
\text { impacts of climate } \\
\text { change on the coastal } \\
\text { through sea-level-rise } \\
\text { and how it affects } \\
\text { coastal development. It } \\
\text { supports the Caribbean } \\
\text { Challenge Initiative to } \\
\text { protect at least } 20 \% \text { of } \\
\text { coastal and marine } \\
\text { areas by 2020. Plans } \\
\text { include ecosystem base } \\
\text { adaptation, early } \\
\text { warning systems. } \\
\text { Lacks details. }\end{array}$ & $\begin{array}{l}\text { (2) Shows the impacts } \\
\text { of climate change on } \\
\text { development. Plans } \\
\text { include vulnerability } \\
\text { risk assessments, } \\
\text { capacity building, } \\
\text { public awareness } \\
\text { programs, and } \\
\text { updating building } \\
\text { codes. Lacks details. }\end{array}$ & $\begin{array}{l}\text { (3) Highlights the } \\
\text { country's vulnerability } \\
\text { to climate change. } \\
\text { Detailed plans include } \\
\text { capacity building and } \\
\text { awareness-building } \\
\text { programs, access to } \\
\text { affordable climate } \\
\text { change-related loans, } \\
\text { and access to } \\
\text { sustainable financing. }\end{array}$ & $\begin{array}{l}\text { (3) Supports } \\
\text { strengthening } \\
\text { institutional capacities, } \\
\text { enhance research and } \\
\text { systematic observation } \\
\text { initiatives, improve the } \\
\text { national, legal and } \\
\text { regulatory framework, } \\
\text { and generate climate, } \\
\text { environmental and } \\
\text { socioeconomic data } \\
\text { and science-based } \\
\text { information. }\end{array}$ & $\begin{array}{l}\text { (2) Recognizes the } \\
\text { impacts of climate } \\
\text { change in the country. } \\
\text { Plans include policy } \\
\text { development to } \\
\text { support climate change } \\
\text { initiatives. } \\
\text { Lacks details. }\end{array}$ \\
\hline mean & 1.75 & 1 & 1 & 2 & 2 & 1.8 & 2.4 & 1.4 \\
\hline
\end{tabular}


Table 5. Coherence between policy documents in SVG, Grenada, and Saint Lucia.

\begin{tabular}{|c|c|c|c|c|c|c|c|c|c|}
\hline & Water Policy & Agriculture Policy & Forestry Policy & Coastal Zone Policy & NDPs & NCCP & NAP & NDC & Total \\
\hline \multicolumn{10}{|l|}{ SVG } \\
\hline Water Policy (2013) & & 1.13 & 1 & 1.13 & 1.18 & 1.58 & 1.58 & 1.18 & 8.78 \\
\hline Agriculture Policy (2016) & 1.13 & & 1.38 & 1.5 & 1.55 & 1.95 & 1.95 & 1.55 & 11.01 \\
\hline Forestry Policy (2016) & 1 & 1.38 & & 1.38 & 1.43 & 1.83 & 1.83 & 1.43 & 10.28 \\
\hline Coastal Zone Policy (2014) & 1.13 & 1.5 & 1.38 & & 1.55 & 1.95 & 1.95 & 1.55 & 11.01 \\
\hline National Development Plans (2012) & 1.18 & 1.55 & 1.43 & 1.55 & & 2 & 2 & 1.6 & 11.31 \\
\hline National Climate Change Policy (2019) & 1.58 & 1.95 & 1.83 & 1.95 & 2 & & 2.4 & 2 & 13.71 \\
\hline Nationally Determined Contributions (2015) & 1.18 & 1.55 & 1.43 & 1.55 & 1.6 & 2 & 2 & & 11.31 \\
\hline Total coherence score & 8.78 & 11.01 & 10.28 & 11.01 & 11.31 & 13.71 & 13.71 & 11.31 & 91.12 \\
\hline \multicolumn{10}{|l|}{ Grenada } \\
\hline Water Policy (2019) & & 1.5 & 1.13 & 1.67 & 1.67 & 1.67 & 1.83 & 1.23 & 10.7 \\
\hline Agriculture Policy (2015) & 1.5 & & 1.38 & 1.88 & 1.88 & 1.88 & 2.08 & 1.48 & 12.08 \\
\hline Forestry Policy (2018) & 1.13 & 1.38 & & 1.5 & 1.5 & 1.5 & 1.7 & 1.1 & 9.81 \\
\hline Coastal Zone Policy (2015) & 1.67 & 1.88 & 1.5 & & 2 & 2 & 2.2 & 1.6 & 12.85 \\
\hline National Development Plans (2020) & 1.67 & 1.88 & 1.5 & 2 & & 2 & 2.2 & 1.6 & 11.22 \\
\hline National Adaptation Plan (2017) & 1.83 & 2.08 & 1.7 & 2.2 & 2.2 & 2.2 & & 1.8 & 14.01 \\
\hline Nationally Determined Contributions (2020) & 1.23 & 1.48 & 1.1 & 1.6 & 1.6 & 1.6 & 1.8 & & 10.41 \\
\hline Total coherence score & 10.7 & 12.08 & 9.81 & 12.85 & 11.22 & 11.81 & 14.01 & 10.41 & 92.89 \\
\hline \multicolumn{10}{|l|}{ Saint Lucia } \\
\hline Water Policy (2018) & & 1.38 & 1.38 & 1.88 & 1.88 & 1.78 & 2.08 & 1.58 & 11.96 \\
\hline Agriculture Policy (2009) & 1.38 & & 1 & 1.5 & 1.5 & 1.4 & 1.7 & 1.2 & 9.68 \\
\hline Forestry Policy (2008) & 1.38 & 1 & & 1.5 & 1.5 & 1.4 & 1.7 & 1.2 & 9.68 \\
\hline Coastal Zone Policy (2020) & 1.88 & 1.5 & 1.5 & & 2 & 1.9 & 2.2 & 1.7 & 12.68 \\
\hline National Development Plans (2011) & 1.88 & 1.5 & 1.5 & 2 & & 1.9 & 2.2 & 1.7 & 12.68 \\
\hline National Climate Change Policy (2013) & 1.78 & 1.4 & 1.4 & 1.9 & 1.9 & & 2.1 & 1.6 & 12.08 \\
\hline National Adaptation Plan (2018) & 2.08 & 1.7 & 1.7 & 2.2 & 2.2 & 2.1 & & 1.9 & 13.88 \\
\hline Nationally Determined Contributions (2021) & 1.58 & 1.2 & 1.2 & 1.7 & 1.7 & 1.6 & 1.9 & & 10.88 \\
\hline Total coherence score & 11.96 & 9.68 & 9.68 & 12.68 & 12.68 & 12.08 & 13.88 & 10.88 & 93.52 \\
\hline
\end{tabular}


Governmental and non-governmental expert interviewed in the three countries highlighted common challenges. These include a lack of coherence between sectors due to a silo approach, lack of coordination in policy implementation, and a lack of political will, driven by the five-year political cycle in the Caribbean. The silo approach noted between the different sectors within the respective countries is one that is ingrained culturally at a national level. One expert from the government sector in SVG noted that, "policies have always been developed by sectors and efforts to have them integrated haven't been very successful." The expert went on to say, "each sector enjoys their little circle of power, hence their unwillingness to share data." One expert in the non-governmental sector in Saint Lucia stated that, "ministries compete among themselves for climate change funding and projects which hinders coordination efforts", while another expert from the governmental sector noted, "the silo approach caused duplication of efforts and in the end the entire country loses." In Grenada, one expert claimed that, "personnels working in the various ministries operate as its their personal business, therefore having a "turf-war" mindset that they should hold on to what is theirs."

At the sectoral level there is an inherent lack of capacity and coordination for the implementation of policies. One expert from the government sector in Saint Lucia stated that, "cross-sector committees set up to implement projects cease to exist because of lack of funding." Such dependency on donor funding is not the best way to enhance policy coherence at the national level. One expert from Grenada stated that, "while the country is grateful to obtain funding from international donors such funding system depended upon in the Caribbean cannot support a policy coherence approach." One expert from the non-governmental sector in SVG noted that, "policy implementation in practice is mainly done by the lead agency." This inhibits a coordinated approach which undermines the process of forming multisectoral committees to develop the policies. Political will is a significant driver to successfully achieve policy coherence [62] and is especially correct in the context of the Caribbean Region.

The majority of experts highlight a lack of political will to enhance coherent policies at the national level. One expert from SVG noted that, "some politicians are only interested in the 'low hanging fruits', things that they can get done, whereas, climate change is perceived as a problem for the ministry of environment or the ministry of agriculture." One expert from Grenada stated that, "Politicians only exercise political will when it involves external funding for new projects." The apparent lack of political will shows that politicians are mainly concern about what they can get done in the five-year political cycle in order to be re-elected, for which they view climate change as needing much longer timeframes. Further, it reflects policy fragmentation, where climate change is often separated from other pressing socio-economic concerns. While there are common challenges amongst the respective countries, each country also faced experiences that were different from each other.

Experts from the governmental and non-governmental sectors of SVG applauded the government's recent institutional restructuring and proactive governance to mainstream adaptation. For example, one expert noted that, "moving the Sustainable Development Unit (SDU) responsible for climate change within the ministry that with responsibilities with economic planning aligns climate change with economic planning and bring more focus to climate change adaptation." Experts however lamented the fact that in its current state, the SDU lacks "teeth" to demand changes in the way policies are developed and planning at the sectoral level because of a lack of legal tools and personnel to effectively execute their role. Specific political problems were highlighted during the discussions. For example, the top-down approach which causes a lack of fluency between politicians and technocrats. One expert noted that, "technocrats are there to guide the politicians, but in many instances, politicians make decisions without that sound guidance of those with the technical capacities." Experts noted that while capacity building is built-in in the policies developed, it is mainly geared towards the technocrats. One expert suggested that, "they 
believe to bridge the gap between the politicians and the technocrats, capacity building should also be geared toward the politicians."

Experts from Grenada mentioned an increased integration of climate change into sectoral policies over the past ten years. They also credited a more integrated approach due to policies being either revised or newly developed to include climate change. They cited the reality of climate change impacts on the country and the support from international funding as fundamental factors. Nevertheless, though overarching documents like the National Adaptation Plan paves the way for adaptation planning and mainstreaming, the trend of adaptation continue to be vastly sector-specific. Several experts mentioned departments' concern with protecting their already limited budget to implement work programs and projects as a major challenge to cross-sectoral collaboration.

An additional primary hindrance to policy coherence is competing development priorities. Experts highlighted that competing development priorities such as health care, poverty alleviation, and improving road networks directly affects the implementation of climate change adaptation. One expert stated that, "the issue of competing development priorities is linked to the region's lack of financial capacity and its prioritization of shortterm development goals." Another barrier is poor planning and management, which affects policy effectiveness and project outcomes. Experts noted that, while the results in Table 4 shows alignment for climate change adaptation between policy documents, the reality on the ground tells another story. One expert highlighted that, "collaborations between departments are ad-hoc and not because of a structured legislative process." The ad hoc nature affects adaptation planning and implementation.

Experts in Saint Lucia, like those in Grenada, mentioned that part of the reason for the country's slightly higher policy coherence is a result of national policies being recently revised or developed to integrate climate change. Experts from both governmental and non-governmental sectors highlighted implementations challenges that affects cross-sectoral climate change adaptation collaboration. The Department of Sustainable Development leads the way to improve climate change awareness and facilitate adaptation mainstreaming across government. The majority of the experts stated that the actions by the Department has helped cross-sectoral communication; however, adaptation planning and responses typically remain project-driven. Although the development policy and climate change policies advocates adaptation mainstreaming (Table 4c) across the water, agriculture, forestry, and coastal zone policies, one expert noted that, "dependency on international donors has delayed implementation." Experts viewed their concerns about the ineffective donor funding model. One expert stated that, "climate change continues to be planned in on a fragmented basis through projects that are funded externally." The lack of financial resources has delayed implementation of adaptation plans in country, while limited human resources are expended on trying to leverage international funding, which was highlighted as a constraint by experts from the governmental and non-governmental sectors.

\section{Discussion}

Policy coherence is essential to ensure sectors are harmonized and to facilitate mainstreaming of climate change adaptation planning. Our analysis shows partial policy coherence for all three countries, with Grenada scoring the highest while Saint Lucia, the lowest. Considering the results of Tables 4 and 5, more effort is needed to advance a more complementary and synergistic policy blend throughout the agriculture, water, coastal zone, and forestry sectors. However, insights from expert interviews focused on challenges such as institutional arrangements, a silo approach, funding mechanisms, and policy implementation indicate that achieving higher policy coherence by itself does not guarantee an improvement on adaptation planning. Policies must align to combat climate change, especially in SIDS with limited financial and human resources. It is also equally important that in practice, the effort has to be a coordinated one.

Policies may be complementary in their goals and in the proposed tools to accomplish their objectives. However, inadequate coordination at the implementation stage can be 
a key barrier [26]. To successfully implement policies, the implementation process has to be precise. The policy should specify the institutional arrangements for implementing the policy instrument, identify the roles and responsibilities within the implementing institutions, highlight the necessary resources, and establish timelines and provisions for monitoring and evaluation. Although SVG, Grenada, and Saint Lucia have all shown their commitment to climate change through the various policy mechanisms and efforts to mainstream climate change, these countries are still behind in practically making their efforts functional. For example, in SVG, the climate change committee set up to guide climate change policies and drive adaptation mainstreaming has been inactive. Experts posited that this might be an indication that competing development priorities are being prioritized. Similar issues have been noted in Cameroon [63] and Nepal [22], in which urgent problems such as job creation, health care, and poverty reduction have all superseded climate change even though it is seen as a high national priority.

The silo approach mentality at the sectoral level, including limited networking and lack of information sharing, hinders the implementation of policies. Although the climate change policies analyzed have established various ministries to achieve the objectives, in practice, there is still no real coordinated approach. All three countries have suffered from this reality, especially as climate change interventions are based on projects where different institutional mechanisms are involved depending on the requirements from the donor agencies, which at times can be overlapping or contradicting overlap each other. Such a silo approach is acknowledged within the sectoral policies in Nepal [22] and Southern Africa $[25,28]$.

Taking into consideration the challenges highlighted in the expert interviews, a sevenstep process is proposed to practically achieve policy coherence by mainstreaming adaptation into the policies and operationalizing them. These initiatives were deduced from the expert interviews. These initiatives can help systematically achieve policy coherence and mainstreaming climate change while operationalizing the policies without adding additional burden. The seven steps are as follows:

1. Update legislations and improve political will to eliminate silo approach between ministries/departments-Strong political will and commitment are essential to mainstream climate change into policies to enhance policy coherence [64,65], with crosssectoral cooperation being another critical factor [66]. Experts from all three countries acknowledged that the silo mentality engrained throughout the varying governmental sectors hinders effective planning and decision making. Policies are guidelines, but to successfully implement the policy, supporting legislations are required [66]. We recommend that legislation be updated to incorporate climate change and earmark the institutions' adaptation planning and implementation.

2. Develop sustainable financial framework-While SIDS are appreciative of donor funding for specific projects, such funding mechanism cannot support policy coherence [24]. Experts reiterated that climate change adaptation measures are expensive, especially for SIDS. They further mentioned that a financial mechanism must be put in place where climate change adaptation is integrated into the government's annual, medium-term, and long-term expenditure and budgetary frameworks and sustained over time. This will include resource mobilization strategies to access international climate change funding for long-term programs.

3. Establish cabinet appointed cross-sectoral committee as an arm of the lead entityNunan et al. [64] concluded that cross-departmental structures could not be relied upon to deliver on policy coherence. Several experts from the three countries also shared this viewpoint as they highlight the ineffectiveness of the currently established committees. Experts indicated that by exercising political will, cabinet members could appoint the necessary committees to mandate a fully functional, cross-sectoral board. Experts highlighted the importance of recommending a key stakeholder in each department to "champion" climate change. That person will also form part of the cross-sectoral committee. A key point also raised by experts with selecting a focal 
person in each department is that if that person leaves, the information ends with that person. Hence, a repository is needed where all the information is stored for continuity and data storage.

4. Establish a central clearing house mechanism managed by the lead entity-Experts cited that a key hindrance in SIDS is the lack of institutional memory, where data is either stored on a shelf or is lost if the person with that data leaves or retires. Experts indicated that the problem could be solved by implementing a clearing-house mechanism as an information source of inventories and data sets. Such a mechanism can be vital in managing and communicating the necessary information [67].

5. Identify capacity needs and training for key personnel-The majority of experts noted that having a more coherent policy mix where climate change is fully mainstreamed can take approximately ten to twelve years. This time frame coincides with that of Robinson [68], where policy-makers suggested that climate change policy coherence could take up to ten years to be fully achieved. Experts highlighted the need for the development of capacity needs which includes training of key personnel. One expert stressed the need for capacity building for both the politicians and technocrats to support informed decision making.

6. Use existing or develop mainstreaming tools-Mainstreaming tools are essential to systematically screen plans, policies, programs, and projects. This is a component of most mainstreaming frameworks and aims to identify the extent to which climate change, risks, and vulnerability have been considered or addressed and whether more should be done [69]. Experts noted that the Caribbean Community Climate Change Center (CCCCC) established Caribbean Climate Online Risk and Adaptation tooL (CCORAL), an online tool to assess climate risk and provide adaptation pathways to help climate resilient decision making and suggested that this tool can be effective in mainstreaming climate change adaptation for greater coherence policies. Experts further indicated that several stakeholders were trained using the tool, but it is not currently used. We recommend that this tool be used across the region, and the more persons are trained.

7. Develop framework for independent reviews-Experts stated the need for an overarching body to audit policies and plans. The approach presents opportunities to integrate a build-measure-learn feedback system into adaptation policy making, contributing to building resilience in SIDS [68]. Experts indicated that audits are necessary, especially as there is a lack of monitoring and evaluation when upon the implementation of projects.

\section{Conclusions}

This paper has assessed the degree in which climate-sensitive sector policies are coherent with each other and with the climate change related policies and development policy in framing climate change adaptation in St. Vincent and the Grenadines, Grenada, and Saint Lucia. Qualitative document analysis, content analysis, and expert interviews were used to analyze and interpret the findings. The findings reveal that many of the sector policies within the three countries either have "limited coherence" or "partial coherence" with climate change adaptation. Taking into consideration the vulnerability of these countries to climate change and their dependency on climate-sensitive sectors, it is essential that the coherence amongst the sector policies is enhanced to create synergies.

Our analysis also highlighted various concerns from the expert interviews, including barriers such as institutional arrangement, silo approach, ineffective financial mechanism, lack of institutional capacity, lack of political will, and limited policy implementation. This calls for coordinated efforts at the cross-sectoral level to prioritize actions and strategies to overcome the many challenges. However, insights from expert interviews highlighted concerns that achieving greater policy coherence alone does not guarantee improved adaptation planning. Other factors such as updated legislation, an enabling environment with a collaborative multi-stakeholder approach, and sustainable financing are necessary. 
Therefore, the paper proposes a seven-step process to address the challenges faced in these countries practically.

Author Contributions: C.T.L. designed the article, conducted the interviews, conducted formal analysis, conducted the interviews and focus group session for validation, and wrote the original draft. M.-C.S. commented on the study design and the methodology, supervision and reviewed the article. All authors have read and agreed to the published version of the manuscript.

Funding: This research was funded by Ministry of Science and Technology (MOST), Taiwan. Funding number: MOST 109-2621-M-259-002 -.

Institutional Review Board Statement: Not applicable.

Informed Consent Statement: Not applicable.

Data Availability Statement: Not applicable.

Acknowledgments: The authors would like to thank all the participants from St. Vincent and the Grenadines, Grenada, and Saint Lucia, CCCCC, CARICOM, IICA, and OECS who participated in the expert interviews. The authors would also like to thank the Ministry of Science and Technology (MOST), Taiwan, under the research project "Pananadengan: Well-living, Wellbeing, and the Sustainable Development Goals for Pongso No Tao" for funding the journal APC payment.

Conflicts of Interest: The authors declare no conflict of interest.

\section{References}

1. Nurse, L.A.; McLean, R.F.; Agard, J.; Briguglio, L.P.; Duvat-Magnan, V.; Pelesikoti, N.; Tompkins, E.; Webb, A. Small Islands; Cambridge University Press: Cambridge, UK; New York, NY, USA, 2014; pp. 1613-1654. [CrossRef]

2. Simpson, M.C.; Clarke, J.F.; Scott, D.J.; New, M.G.; Karmalkar, A.V.; Day, O.; Taylor, M.A.; Gossling, S.; Wilson, M.; Chadee, D.D.; et al. The Caribsave Climate Change Risk Atlas. 2012. Climate Change Risk Profile for Saint Vincent and the Grenadines. Available online: https://www.researchgate.net/publication/272791668_Climate_Change_Risk_Profile_for_Saint_Vincent_and_ the_Grenadines (accessed on 10 October 2020).

3. UNTWO. Climate Change and Tourism: Responding to Global Challenges. 2008. Available online: https://sdt.unwto.org/sites / all/files/docpdf/climate2008.pdf (accessed on 30 January 2021).

4. UN-OHRLLS. Small Island Developing States in Numbers: Climate Change Edition. 2015. Available online: https: / / sustainabledevelopment.un.org/content/documents/2189SIDS-IN-NUMBERS-CLIMATE-CHANGE-EDITION_2015.pdf (accessed on 15 September 2020).

5. Robinson, S. Adapting to climate change at the national level in Caribbean small island developing states Island. Stud. J. 2018, 13, 79-100. [CrossRef]

6. Thomas, A.; Lindo, S. Disappearing islands: Small island developing states and climate change. In Environment Issues and Policy: Exploring Past, Present and Future Socioecological Relations, 1st ed.; Chatterjee, M., Svyatets, E., Eds.; Cognella: San Diego, CA, USA, 2019; pp. 172-181.

7. Wilkinson, E.; Twigg, J.; Few, R. Building back Better: A Resilient Caribbean after the 2017 Hurricanes. Available online: https://www.odi.org/sites/odi.org.uk/files/resource-documents/12028.pdf (accessed on 15 November 2020).

8. Mycoo, M.A. Beyond $1.5^{\circ} \mathrm{C}$ : Vulnerabilities and adaptation strategies for Caribbean Small Island Developing States. Reg. Environ. Chang. 2018, 18, 2341-2353. [CrossRef]

9. Barros, V.R.; Field, C.B.; Dokken, D.J.; Mach, K.J.; Mastrandrea, M.D.; Bilir, T.E.; Chatterjee, M. Climate Change 2014: Impacts, Adaptation, and Vulnerability. Part B: Regional Aspects. Contribution of Working Group II to the Fifth Assessment Report of the Intergovernmental Panel on Climate Change; Cambridge University Press: Cambridge, UK; New York, NY, USA, 2014.

10. Government of Dominica. Budget: From Survival to Sustainability and Success: A Resilient Dominica.Rep., Government of Dominica, Roseau. 2018. Available online: http:/ / finance.gov.dm/budget/budget-addresses/file/27-budget-address-2018-2019from-survival-to-sustainability-and-success-a-resilient-dominica (accessed on 15 March 2021).

11. World Bank. A 360 Degree Look at Dominica Post Hurricane Maria. 2017. Available online: http:/ /www.worldbank.org/en/ news / feature/2017/11/28/a-360-degree-look-at-dominica-post-hurricane-maria (accessed on 10 February 2021).

12. Dryzek, J.S.; Stevenson, H. Global democracy and earth system governance. Ecol. Econ. 2011, 70, 1865-1874. [CrossRef]

13. Agrawala, S. Adaptation, development assistance and planning: Challenges and opportunities. IDS Bull. 2004, 35, 50. [CrossRef]

14. CCCCC. 5 Things to Know About Climate Change in the Caribbean! Caribbean Community Climate Change Centre. 2014. Available online: http:/ / caribbeanclimateblog.com/ (accessed on 10 February 2021).

15. Brown, J.N.; Gupta, A.S.; Brown, J.R.; Muir, L.C.; Risbey, J.S.; Whetton, P.; Zhang, X.; Ganachaud, A.; Murphy, B.; Wijffels, S.E. Implications of CMIP3 model biases and uncertainties for climate projections in the western tropical Pacific. Clim. Chang. 2013, 119, 147-161. [CrossRef] 
16. Darylmple, S.P.; Mason-Case, S. Inside Story: Strengthening Climate Resilience-The Case of Grenada. Caribbean Policy Development Centre, International Development Law Organization. 2012. Available online: https://cdkn.org/resource/\%2 0inside-story\%20strengthening-climate-resilience-the-case-of-grenada/?loclang=en_gb (accessed on 12 March 2021).

17. Lafferty, W.; Hovden, E. Environmental policy integration: Towards an analytical framework. Environ. Politics 2003, 12, 1-22. [CrossRef]

18. Brodhag, C.; Taliere, S. Sustainable development strategies: Tools for policy coherence. Nat. Resour. Forum 2006, 30, 136-145. [CrossRef]

19. Huttunen, S.; Kivimaa, P.; Virkamäki, V. The need for policy coherence to trigger a transition to biogas production. Environ. Innov. Soc. Transit. 2014, 12, 14-30. [CrossRef]

20. Behboudi, R.; Majid, M.R.; Johar, F. Horizontal coherence in environmental policies of Iskandar Malaysia. J. Teknol. 2015, 73, 139-146. [CrossRef]

21. Duraiappah, A.K.; Bhardwaj, A. Measuring Policy Coherence among the MEAs and MDGs; International Institute for Sustainable Development (IISD): Winnipeg, MB, Canada, 2007.

22. Ranabhat, S.; Ghate, R.; Bhatta, L.D.; Agrawal, N.K.; Tankha, S. Policy Coherence and Interplay between Climate Change Adaptation Policies and the Forestry Sector in Nepal. Environ. Manag. 2018, 61, 968-980. [CrossRef]

23. Antwi-Agyei, P.; Dougill, A.; Stringer, L. Assessing Coherence between Sector Policies and Climate Compatible Development: Opportunities for Triple Wins. Sustainability 2017, 9, 2130. [CrossRef]

24. Scobie, M. Policy coherence in climate governance in Caribbean Small Island Developing States. Environ. Sci. Policy 2016, 58, 16-28. [CrossRef]

25. Kalaba, F.K.; Quinn, C.H.; Dougill, A.J. Policy coherence and interplay between Zambia's forest, energy, agricultural and climate change policies and multilateral environmental agreements. Int. Environ. Agreem. Politics Law Econ. 2013, 14, 181-198. [CrossRef]

26. Nilsson, M.; Zamparutti, T.; Petersen, J.E.; Nykvist, B.; Rudberg, P.; McGuinn, J. Understanding Policy Coherence: Analytical Framework and Examples of Sector-Environment Policy Interactions in the EU. Environ. Policy Gov. 2012, 22, 395-423. [CrossRef]

27. Urwin, K.; Jordan, A. Does public policy support or undermine climate change adaptation? Exploring policy interplay across different scales of governance. Glob. Environ. Chang. 2008, 18, 180-191. [CrossRef]

28. England, M.I.; Dougill, A.J.; Stringer, L.C.; Vincent, K.E.; Pardoe, J.; Kalaba, F.K.; Afionis, S. Climate change adaptation and cross-sectoral policy coherence in southern Africa. Reg. Environ. Chang. 2018, 18, 2059-2071. [CrossRef]

29. Kuruppu, N.; Liverman, D. Mental preparation for climate adaptation: The role of cognition and culture in enhancing adaptive capacity of water management in Kiribati. Glob. Environ. Chang. 2011, 21, 657-669. [CrossRef]

30. The World Bank. World Development Indicators Databank. Available online: https://databank.worldbank.org/source/worlddevelopment-indicators (accessed on 3 March 2021).

31. World Data Atlas. St. Vincent and the Grenadines. Available online: https://knoema.com/atlas/Saint-Vincent-and-theGrenadines/topics/Tourism/Travel-and-Tourism-Total-Contribution-to-GDP/Contribution-of-travel-and-tourism-to-GDPpercent-of-GDP (accessed on 3 March 2021).

32. World Data Atlas. Saint Lucia. Available online: https://knoema.com/atlas/Saint-Lucia/topics/Tourism/Travel-and-TourismTotal-Contribution-to-GDP/Contribution-of-travel-and-tourism-to-GDP-percent-of-GDP (accessed on 3 March 2021).

33. World Data Atlas. Grenada. Available online: https://knoema.com/atlas/Grenada/topics/Tourism/Travel-and-Tourism-TotalContribution-to-GDP/Contribution-of-travel-and-tourism-to-GDP-percent-of-GDP (accessed on 3 March 2021).

34. Altheide, D.; Coyle, M.; DeVriese, K.; Schneider, C. Emergent qualitative document analysis. In Handbook of Emergent Methods; Hesse-Biber, S.N., Leavy, P., Eds.; The Guilford Press: New York, NY, USA, 2008; pp. 127-151.

35. Government of St. Vincent and the Grenadines. Draft Water Safety Plan. Private communication, 2013.

36. Government of Grenada. National Water Policy. 2019. Available online: https://climatefinance.gov.gd/wp-content/uploads/20 19/10/Final_Draft_Grenada_National_Water_Policy_Feb.28.pdf (accessed on 5 February 2021).

37. Government of Saint Lucia. Sectoral Adaptation Strategy and Action Plan for the Water Sector (2018-2028). 2018. Available online: https:/ / www4.unfccc.int/sites/NAPC/Documents/Parties/Saint\%20Lucia\%20Sectoral\%20Adaptation\%20Plan\%20 for\%20Water.pdf (accessed on 8 February 2021).

38. Government of St. Vincent and the Grenadines. National Agriculture, Fisheries and Forestry Sector Development Plan (2017-2025). Private communication, 2016.

39. Government of Grenada. National Agriculture Plan. 2015. Available online: https://agricarib.org/images/docs/COUNTRIES_ GRENADA_National_Agriculture_Plan_Final_Aug25_2015_Final_Edit_(002).pdf (accessed on 5 February 2021).

40. Government of Saint Lucia. Sectoral Adaptation Strategy and Action Plan for the Agriculture Sector (2018-2028). 2018. Available online: https:/ / www4.unfccc.int/sites/NAPC/Documents/Parties/Saint\%20Lucia\%E2\%80\%99s\%20Sectoral\%20Strategy\%20 and\%20Action\%20Plan\%20for\%20Agriculture.pdf (accessed on 8 February 2021).

41. Government of Grenada. Revised Forestry Policy. 2018. Available online: https://gov.gd/sites/mocr/files/docs/Documents/ Grenada\%20Forest\%20Policy.pdf (accessed on 5 February 2021).

42. Government of Saint Lucia. Forest Policy. 2008. Available online: http://www.caribbeanelections.com/eDocs/strategy/lc_ strategy/1c_Forest_Policy_2008.pdf (accessed on 8 February 2021).

43. Government of St. Vincent and the Grenadines. National Ocean Policy and Action Plan. Private communication, 2014.

44. Government of Grenada. Integrated Coastal Zone Management Policy. 2015. Available online: http://extwprlegs1.fao.org/docs/ pdf/grn181100.pdf (accessed on 5 February 2021). 
45. Government of Saint Lucia. National Ocean Policy. Private communication, 2021.

46. Government of St. Vincent and the Grenadines. St. Vincent and the Grenadines Intended Nationally Determined Contribution. 2015. Available online: https://www4.unfccc.int/sites/ndcstaging/PublishedDocuments/Saint\%20Vincent\%20and\%20 Grenadines\%20First/Saint\%20Vincent\%20and\%20the\%20Grenadines_NDC.pdf (accessed on 10 February 2020).

47. Government of Grenada. Second Nationally Determined Contributions. 2020. Available online: https://www4.unfccc.int/ sites/ndcstaging/PublishedDocuments/Grenada\%20Second/GrenadaSecondNDC2020\%20-\%2001-12-20.pdf (accessed on 5 February 2021).

48. Government of Saint Lucia. Nationally Determined Contributions. 2021. Available online: https://www4.unfccc.int/sites/ ndcstaging/PublishedDocuments/Saint\%20Lucia\%20First/Saint\%20Lucia\%20First\%20NDC\%20(Updated\%20submission) .pdf (accessed on 8 February 2021).

49. Government of St. Vincent and the Grenadines. National Economic and Social Development Plan (2013-2025). 2012. Available online: http:/ / finance.gov.vc/finance/index.php/economic-planning-industry-and-social-development/national-economica-social-development-plan (accessed on 30 January 2020).

50. Government of Grenada. National Sustainable Development Plan. 2019. Available online: https://observatorioplanificacion. cepal.org/sites/default/ files/plan/files/GRANADA-NSDP20202035.pdf (accessed on 5 February 2021).

51. Government of Saint Lucia. Medium-Term Development Strategic Plan. 2011. Available online: https://cepei.org/wp-content/ uploads/2020/01/St.-Lucia-Medium-Term-Development-Strategic-Plan.pdf. (accessed on 8 February 2021).

52. Government of St. Vincent and the Grenadines. National Climate Change Policy. 2019. Available online: http://assembly.gov.vc/ assembly/images / ActsBillsPolicies/SVG_National_Climate_Change_Policy.pdf (accessed on 30 January 2020).

53. Government of Grenada. National Climate Change Policy (2017-2021). 2017. Available online: https://www4.unfccc.int/ sites/NAPC/Documents/Parties/Grenada_National\%20Climate\%20Change\%20Policy\%202017-2021.pdf (accessed on 5 February 2021).

54. Government of Saint Lucia. Climate Change Adaptation Policy. 2013. Available online: http://extwprlegs1.fao.org/docs/pdf/ stl192161.pdf (accessed on 8 February 2021).

55. Government of St. Vincent and the Grenadines. National Adaptation Plan. 2019. Available online: https://www4.unfccc.int/ sites/NAPC/Documents/Parties/FINAL\%20NAP_SVG_Approved.pdf (accessed on 30 January 2020).

56. Government of Grenada. National Climate Change Adaptation Plan (2017-2021). 2017. Available online: https://www4 .unfccc.int/sites/NAPC/Documents/Parties/Grenada_National\%20Adaptation\%20Plan_\%202017-2021.pdf (accessed on 5 February 2021).

57. Government of Saint Lucia. National Adaptation Plan (2018-2028). 2018. Available online: https://www4.unfccc.int/sites/ NAPC/Documents/Parties/SLU-NAP-May-2018.pdf (accessed on 8 February 2021).

58. Le Gouais, A.; Wach, E. A qualitative analysis of rural water sector policy documents. Water Altern. 2013, 6, 439-461.

59. Vincent, K.; Dougill, A.; Dixon, J.L.; Stringer, L.C.; Cull, T. Identifying climate services needs for National planning: Insights from Malawi. Clim. Policy 2015, 17, 189-202. [CrossRef]

60. Dietz Hope, C.; Patmore, N. Some economics of 'dangerous' climate change: Reflections on the stern review. Glob. Environ. Chang. 2007, 17, 311-325. [CrossRef]

61. Adger, W.N.; Agrawala, S.; Mirza, M.M.Q.; Conde, C.; O’Brien, K.; Pulhin, J.M.; Pulwarty, R.; Smit, B.; Takahashi, K. Contribution of Working Group II to the Fourth Assessment Report of the Intergovernmental Panel on Climate Change. In Assessment of Adaptation Practices, Options, Constraints and Capacity. Climate Change: Impacts, Adaptation and Vulnerability; Parry, M.L., Canziani, O.F., Palutikof, J.P., van der Linden, P.J., Hanson, C.E., Eds.; Cambridge Univ Press: Cambridge, UK, 2007 ; pp. $717-743$.

62. Chayes, A.; Chayes, A.H. On compliance. Int. Organ. 1993, 47, 175. [CrossRef]

63. Brown HC, P.; Nkem, J.N.; Sonwa, D.J.; Bele, Y. Institutional adaptive capacity and climate change response in the Congo Basin forests of Cameroon. Mitig. Adapt. Strateg. Glob. Chang. 2010, 15, 263-282. [CrossRef]

64. Nunan, F.; Campbell, A.; Foster, E. Environmental Mainstreaming: The Organizational Challenges of Policy Integration. Public Adm. Dev. 2012, 32, 262-277. [CrossRef]

65. Saito, N. Mainstreaming climate change adaptation in least developed countries in South and Southeast Asia. Mitig. Adapt. Strateg. Glob. Chang. 2012, 18, 825-849. [CrossRef]

66. Helvetas, N. Nepal's Climate Change Policies and Plans: Local Communities' Perspective Environment and Climate Series 2011/1. HELVETAS Swiss Inter-Cooperation Nepal: Kathmandu, Nepal, 2011.

67. Pervin, M.; Sultana, S.; Phirum, A.; Camara Isatou, F.; Nzau, V.M.; Phonnasane, V.; Khounsy, P.; Kaur, N.; Anderson, S. A Framezork for Mainstreaming Climate Resilience into Development Planning; International Institute for Environment and Development: London, UK, 2013.

68. Robinson, S.A. Mainstreaming climate change adaptation in small island developing states. Clim. Dev. 2019, 11, 47-59. [CrossRef]

69. Klein, R.J.T.; Eriksen, S.E.H.; Næss, L.O.; Hammill, A.; Tanner, T.M.; Robledo, C.; O’Brien, K.L. Portfolio screening to support the mainstreaming of adaptation to climate change into development assistance. Clim. Chang. 2007, 84, 23-44. [CrossRef] 